Titiek Herwanti \& Animah: Diskriminan dan Konsekuensi Komitmen Organisasi

\title{
DETERMINAN DAN KONSEKUENSI KOMITMEN ORGANISASI
}

\author{
Titiek Herwanti \\ Animah \\ (FEB Universitas Mataram)
}

\begin{abstract}
ABSTRAK
Tujuan penelitian ini adalahterciptanya budaya manajemen syariah, sosok pemimpin yang memiliki keahlian manajerial, dan adanya sistem reward untuk memotivasi karyawan, agar tercipta komitmen organisasi sehingga berimplikasi terhadap peningkatkan kinerja karyawan yang pada akhirnya meningkatkan kinerja perusahaan secara keseluruhan. Populasi penelitian ini adalah seluruh karyawandi KSPPS (Koperasi Simpan Pinjam Pembiayaan Syariah) di pulau Lombok (49 KSPPS) dengan metode judgment sampling.Variabel penelitian budaya manajemen syariah, gaya kepemimpinan, system reward, komitmen organisasi, dan kinerja karyawan. Alat analisis yang digunakan adalah Partial Least Square Hasil penelitian menunjukkan bahwa variable budaya manajemen syariah, gaya kepemimpinan, dan sistem reward berpengaruh terhadap komitmen organisasi dan kinerja karyawan. Variabel komitmen organisasi terbukti sebagai variabel intervening dari budaya manajemen syariah ke kinerja karyawan, tetapi tidak untuk gaya kepemimpinan dan sistem reward ke kinerja karyawan.Implikasi dari penelitian ini adalah manajemen pengelolaan di KSPPS sebaiknya di dalam memberikan pelayanan mempunyai nilai-nilai yang berbasis budaya manajemen syariah karena terbuktimemberikan pengaruh yang cukup besar agar karyawan berkomitmen terhadap pekerjaan sehingga menghasilkan kinerja karyawan yang diharapkan berdampakterhadap peningkatan kinerja perusahaan secara keseluruhan.
\end{abstract}

Keyword : Budaya Organisasi, Gaya Kepemimpinan, Sistem Reward, Knowledge Management, Komitmen Organisasi, Kinerja Karyawan

\section{PENDAHULUAN}

KSPPS (Koperasi Simpan Pinjam Pembiayaan Syariah) merupakan salah satu lembaga keuangan yang menawarkan konsep keuangan dengan mekanisme bagi hasil atau system profit and loss sharing (PLS) yang merupakan core produk bagi lembaga keuangan syariah, yang sesuai dengan ajaran agama islam.Sedangkan prinsip bagi hasil yang banyak digunakan 
adalah murabahah dari pada dan mudharabah karena memberikan resiko yang paling kecil. Oleh karena prinsip bagi hasil menggunakan murabahah, maka diperlukan sumber daya manusia yang berkualitas di dalam memberikan pelayanan kepada nasabah,karena hal ini akan dapat meningkatkan kinerja karyawan yang pada akhirnya meningkatkan kinerja organisasi.

Budaya organisasi diperlukan oleh karyawan di dalam pengelolaan organisasi agar tercapai tujuan organisasi. Hal ini diperkuat oleh peneliti sebelumnya bahwa budaya mempengaruhi kinerja karyawan (Nurjanah, 2008; Arifin, 2010; Setyorini et.al, 2012; Kurniawan et.al, 2012 dan Susilo, 2013). Selain itu apabila dalam melaksanakan pekerjaannya karyawan berpedoman pada budaya organisasi, maka hal ini akan membuat mereka komitmen terhadap oragnisasinya (Arifin,2010). Dalam teori planned behavior pendekatan terhadap beliefs dapat mendorong individu melakukan perilaku tertentu. Munculnya sikap yang mempengaruhi prilaku melalui suatu proses yang teliti dan beralasan.

Selanjutnya Alberto et al (2005) menyatakan bahwa kepemimpinan berpengaruh positif terhadap kinerja. Selain itu dalam path goal theory dijelaskan dampak perilaku pimpinan pada motivasi bawahan bahwa pemimpin dapat mengubah karyawan untuk komitmen terhadap pekerjaan mereka.Yousef (2000) menyatakan bahwa komitmen organisasi memediasi hubungan antara perilaku kepemimpinan dengan kinerja, di mana anggota organisasi lebih puas dengan pekerjaannya dan kinerja mereka menjadi tinggi

Selanjutnya Luthans (2006) juga menyatakan bahwa salah satu yang mendapat perhatian makin besar adalah penghargaan terhadap karyawan karena banyak karyawan memiliki tanggung jawab atas pekerjaan dan keluarga, dan ketika organisasi membantu mereka menangani kewajiban tersebut, loyalitas mereka pun meningkat. Artinya karyawan bekerja dengan tujuan untuk memenuhi kebutuhan hidupnya yang dalam theory kebutuhan maslow dinyatakan bahwa ada lima tingkatan kebutuhan yaitu : physiological needs, safety needs, social needs, esteem needs, dan self actualization.Menurut Supratiningrum dan Zulaikha (2003) system reward berpengaruh terhadap kinerja dengan asumsi bahwa Reward berbasis kinerja mendorong karyawan mengubah kecenderungan mereka dari semangat untuk memenuhi kepentingan diri sendiri ke semangat untuk memenuhi tujuan organisasi. Hal ini di dukung penelitian terdahulu bahwa system reward berpengaruh terkinerja karyawan (Ruvendi, 2005 ; Sinaga, 2008). Sedangkan Donia (2011) menyatakan bahwa system reward berpengaruh terhadap komitmen organisasi. 
Titiek Herwanti \& Animah: Diskriminan dan Konsekuensi Komitmen Organisasi

Berdasarkan uraian di atas penelitian ini memfokuskan pada aspek Budaya organisasi, Gaya Kepemimpinan, systemreward, komitmen organisasi, dan kinerja karyawan. Penelitian ini berbeda dengan penelitian terdahulu dalam hal penggunaan budaya organisasi menggunakan budaya manajemen syariah yang belumpernah digunakan untuk menjelaskan komitmen organisasi. Selain itu penelitian ini juga menguji dampak komitmen organisasi terhadap kinerja karyawan yang diukur tidak hanya gaya kepemimpinan malainkan dengan budaya organisasi (budaya manajemen syariah) dan system reward.

\section{TELAAH PUSTAKA DAN PENGEMBANGAN HIPOTESIS}

\section{Teori Planned Behavior, Path Goal Teory, Need Hierarchy Theory, Teori Penguatan}

Teori planned behavior merupakan pendekatan terhadap beliefs yang dapat mendorong individu untuk melakukan perilaku tertentu (Fishbein dan Ajzen dalam Yuliana, 2004). Munculnya sikap yang memengaruhi perilaku adalah melalui suatu proses pengambilan keputusan yang teliti dan beralasan, dan dampaknya terbatas hanya pada tiga hal, yaitu: (a) perilaku tidak banyak ditentukan oleh sikap umum, tetapi oleh sikap spesifik terhadap suatu perilaku; (b) perilaku tidak hanya dipengaruhi oleh sikap, tetapi juga dipengaruhi oleh norma subyektif; (c) sikap terhadap perilaku bersama dengan norma subyektif membentuk intensi untuk melakukan suatu perilaku tertentu (Fishbein \& Ajzen, 1975).

Path goaltheorymenjelaskan dampak perilaku pimpinan pada motivasi bawahan, kepuasan dan kinerjanya. Ada empat gaya kepemimpinan menurut Robert House, yaitu direktif, suportif, partisipatif dan berorientasi pada prestasi.

Teori kebutuhan Maslow mengidentifikasi lima tingkat dalam hirarki kebutuhan yaitu kebutuhan fisiologis (gaji, sandang, pangan, papan), kebutuhan keamanan (rencana senioritas, asuransikesehatan, uang pesangon, pensiun), kebutuhan cinta, kebutuhan pekerjaan dan aktualisasi diri.

Teori penguatan ini mengemukakan bahwa perilaku merupakan fungsi dari akibat yang berkaitan dengan perilaku tersebut. Teori penguatan memiliki kontinjensi penguatan yaitu berkaitan dengan urutan-urutan antara stimulus, tanggapan, dan konsekuensi dari perilaku yang ditimbulkan. Suatu kondisi kerja tertentu dibentuk oleh organisasi (stimulus), kemudian karyawan bertindak sebagaimana diinginkan oleh organisasi (tanggapan). Dari sudut pandang motivasi, penggunaan stimulus atau konsekuensi akan 
memotivasi karyawan untuk melakukan perilaku yang diinginkan oleh organisasi. Semakin pendek interval waktu antara tanggapan atau respon karyawan dengan pemberian imbalan maka semakin besar pengaruhnya terhadap perilaku.

\section{Hipotesis}

\section{Budaya Organisasi, Gaya Kepemimpina, Sistem Reward, dan Komitmen Organisasi}

Budaya Organisasi berfungsi sebagai perekat, pemersatu, identitas, citra, motivator bagi seluruh karyawan dan orang-orang yang ada di dalamnya (Arifin, 2010). Hasil penelitian Arifin (2010), Nurjanah (2008), Setyporini, et al (2012), dan Praptadi (2009) memberikan bukti empiris bahwa budaya berpengaruh terhadap komitmen organisasi.

Kepemimpinan (leadership styles) merupakan cara pimpinan untuk mempengaruhi orang lain/bawahannya sedemikian rupa sehingga orang tersebut mau melakukan kehendak pemimpin untuk mencapai tujuan organisasi meskipun secara pribadi hal tersebut mungkin tidak disenangi (Luthans, 2002). Fleishman et al., dalam Gibson (1996) telah meneliti gaya kepemimpinan di Ohio State University tentang perilaku pemimpin melalui dua dimensi, yaitu: consideration dan initiating structure. Consideration (konsiderasi) adalah gaya kepemimpinan yang menggambarkan kedekatan hubungan antara bawahan dengan atasan, adanya saling percaya, kekeluargaan, menghargai gagasan bawahan, dan adanya komunikasi antara pimpinan dengan bawahan. Pemimpin yang memiliki konsiderasi yang tinggi menekankan pentingnya komunikasi yang terbuka dan parsial. Initiating structure (struktur inisiatif) merupakan gaya kepemimpinan yang menunjukkan bahwa pemimpin mengorganisasikan dan mendefinisikan hubungan dalam kelompok, cenderung membangun pola dan saluran komunikasi yang jelas, menjelaskan cara mengerjakan tugas yang benar. Hasil penelitian Nafisah (2005), Damayanti (2013), Santoso (2015), Ying dan Ahmad (2009), Desiyanti (2005) menyatakan bahwa gaya kepemimpinan berpengaruh terhadap komitmen organisasi.

Reward adalah ganjaran, hadiah, penghargaan atau imbalan yang bertujuan agar seseorang menjadi lebih giat lagi usahanya untuk memperbaiki atau meningkatkan kinerja yang telah dicapai (Nugroho, 2006). Sedangkan Wibowo (2013) menyatakan bahwa reward adalah tambahan penerimaan yang sering kali diberikan selain gaji dan intensif oleh pimpinan dalam upaya lebih menghargai kinerja pekerjanya. Hasil penelitian Donia (2011) menyatakan bahwa system reward berpengaruh terhadap komitmen organisasi. 
Titiek Herwanti \& Animah: Diskriminan dan Konsekuensi Komitmen Organisasi

\section{$H_{1}$ : budaya organisasi, gaya kepemimpinan, dan system rewad berpengaruh terhadap komitmen organisasi}

\section{Budaya Organisasi, Gaya Kepemimpinan, Sistem Reward, Komitmen dan Kinerja Karyawan}

Budaya Organisasi berfungsi sebagai perekat, pemersatu, identitas, citra, motivator bagi seluruh karyawan dan orang-orang yang ada di dalamnya (Arifin, 2010). Hasil penelitian Arifin (2010), Nurjanah (2008), Setyporini, et al (2012), dan Praptadi (2009) memberikan bukti empiris bahwa budaya berpengaruh terhadap kinerja karyawan.

Kepemimpinan (leadership styles) merupakan cara pimpinan untuk mempengaruhi orang lain/bawahannya sedemikian rupa sehingga orang tersebut mau melakukan kehendak pemimpin untuk mencapai tujuan organisasi meskipun secara pribadi hal tersebut mungkin tidak disenangi (Luthans, 2002). Fleishman et al., dalam Gibson (1996) telah meneliti gaya kepemimpinan di Ohio State University tentang perilaku pemimpin melalui dua dimensi, yaitu: consideration dan initiating structure. Consideration (konsiderasi) adalah gaya kepemimpinan yang menggambarkan kedekatan hubungan antara bawahan dengan atasan, adanya saling percaya, kekeluargaan, menghargai gagasan bawahan, dan adanya komunikasi antara pimpinan dengan bawahan. Pemimpin yang memiliki konsiderasi yang tinggi menekankan pentingnya komunikasi yang terbuka dan parsial. Initiating structure (struktur inisiatif) merupakan gaya kepemimpinan yang menunjukkan bahwa pemimpin mengorganisasikan dan mendefinisikan hubungan dalam kelompok, cenderung membangun pola dan saluran komunikasi yang jelas, menjelaskan cara mengerjakan tugas yang benar. Hasil penelitian Damayanti (2013), Maramis (2013), Shea (1999), Trisnaningsih (2007), Risqon dan Purwadi (2012), Brahmasari dan Suprayitno (2009), Yousef (2000), Kusumawati (2008), Heriyanti (2007), Nurjanah (2008), Mariam (2009), Fadli (2004) menyatakan bahwa gaya kepemimpinan berpengaruh terhadap kinerja karyawan.

Reward adalah ganjaran, hadiah, penghargaan atau imbalan yang bertujuan agar seseorang menjadi lebih giat lagi usahanya untuk memperbaiki atau meningkatkan kinerja yang telah dicapai (Nugroho, 2006). Sedangkan Wibowo (2013) menyatakan bahwa reward adalah tambahan penerimaan yang sering kali diberikan selain gaji dan intensif oleh pimpinan dalam upaya lebih menghargai kinerja pekerjanya. Menurut Supratiningrum dan Zulaikha (2003) system reward berpengaruh terhadap kinerja dengan asumsi bahwa Reward berbasis kinerja mendorong karyawan mengubah kecenderungan mereka dari semangat untuk memenuhi kepentingan diri 
sendiri ke semangat untuk memenuhi tujuan organisasi. Reward berbasis kinerja memberi dua manfaat: memberi informasi dan memberikan motivasi (Mulyadi, 2007).Sedangkan menurut Mardiyah dan Listianingsih (2005) menyatakan bahwa total quality managemen yang berinteraksi dengan system reward berpengaruh negative terhadap kinerja manajerial. Hasil penelitian Mardiyah dan Listianingsih (2005) dan Febrianti et al. (2014) menyatakan bahwa system reward berpengaruh terhadap kinerja karyawan.

Komitmen organisasi adalah perasaan sebagai keterkaitan atau keterikatan fisik pegawai terhadap organisasi psikologis dan fisik pegawai terhadap organisasi tempat ia bekerja atau organisasi dimana ia menjadi anggotanya (Wirawan, 2013). Sedangkan menurut Abdullah (2012) komitmen adalah keyakinan yang mengikat seseorang sedemikian rupa kukuhnya dan menggerakkan perilakunya menuju kearah tujuan yang diyakininya. Menurut Mayer dan Allen dalam Ikhsan dan Ishak (2005) ada tiga komponen mengenai komitmen organisasi yaitu :

a. Komitmen Afektif, terjadi apabila karyawan ingin menjadi bagian dari organisasi karena adanya ikatan emosional (emotional attachment) atau psikologis terhadap organisasi

b. Komitmen Kontinu, muncul apabila karyawan tetap pada suatu organisasi karena membutuhkan gaji dan keuntungan lain atau karena karyawan tersebut tidak menemukan pekerjaan lain.

c. Komitmen normative, timbul dari nilai-nilai karyawan atau karyawan tinggal diorganisasi karenadia merasa berkewajiban untuk itu.

Menurut Verscheor dalam Abdullah (2012) perusahaan yang memiliki komitmen terhadap nilai-nilai moral lebih berhasil secara financial dibanding perusahaan yang tidak memiliki komitmen moral. Selain itu menurut Arifin (2012) apabila karyawan memiliki komitmen yang tinggi atas pekerjaannya, maka akan dihasilkan kinerja yang bagus. Hasil penelitian Tobing (2009), Ying dan Ahmad (2009), Suwardi dan Utomo (2011, Heriyanti (2007), Nurjanah (2008), Praptadi (2009) menyatakan bahwa komitmen organisasiberpengaruh terhadap kinerja karyawan.

$\mathrm{H}_{2}$ : budaya organisasi, gaya kepemimpinan, system reward dan komitmen organisasi berpengaruh terhadap kinerja karyawan

\section{Hipotesis Mediasi}

Dengan mengacu pada teori planned behavior, teori path goal, teori kebutuhan maslow (need hierarchy theory) dan teori penguatandan penelitian terdahulu di atas, maka dalam penelitian ini memasukkan komitmen organisasi merupakan variabel mediasi.Hal ini diperkuat oleh penelitian Yousef (2000) yang menyatakan bahwa komitmen organisasi 
Titiek Herwanti \& Animah: Diskriminan dan Konsekuensi Komitmen Organisasi

memediasi hubungan antara gaya kepemimpinan dan kinerja melalui komitmen organisasi, tetapi dalam penelitian ini kami mencoba untuk membuktikan apakah komitmen organisasi juga memediasi hubungan antara budaya organisasi dan system reward dengan kinerja karyawan.

$\mathrm{H}_{3}$ : Budaya organisasi, Gaya kepemimpinan, Sistem reward berpengaruh tidak langsung terhadap kinerja melalui komitmen karyawan

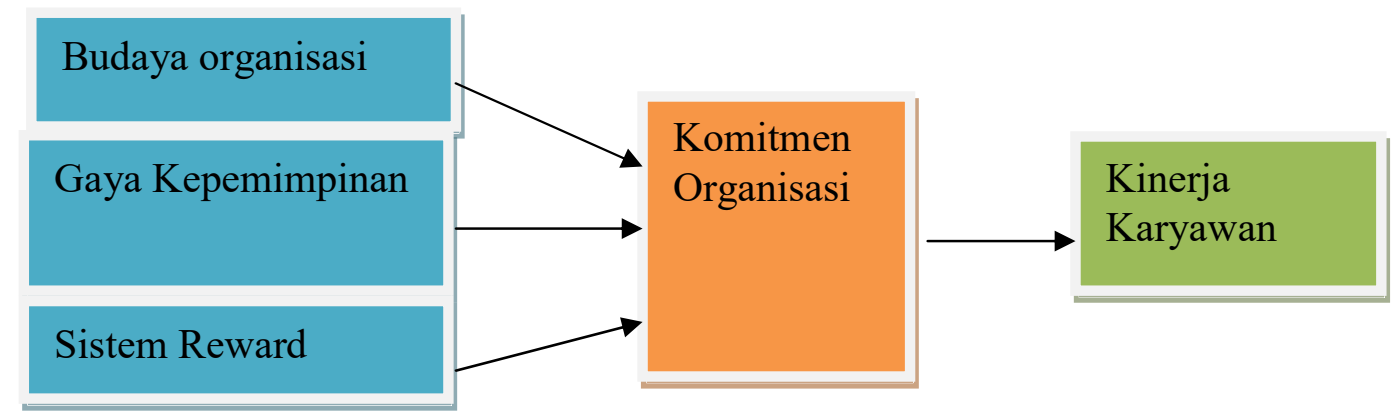

Gambar 1 : Peta Jalan Penelitian

METODE PENELITIAN

Jenis penelitian ini adalah penelitian asosiatif dengan sumber data primer dengan cara pemberian kuesioner kepada karyawan KSPPS di Pulau Lombok.Populasi dalampenelitian iniadalah karyawan yang bekerja pada lembaga keuangan mikro syariah (49KSPPS) dengan teknik sampling menggunakan metode purposive sampling dengan kriteria memiliki masa kerjaminimal 2 tahun dan terlibat langsung di dalam operasional KSPPS.

Variabel-variabel dalam penelitian berupa variable independen yang terdiri dari budaya organisasi (X1), gaya kepemimpinan (X2), dan sistem reward (X4), variabel komitmen organisasi sebagai variabel intervening (Z), dan variabel kinerja sebagai variabel dependen $(Y)$.

1. Budaya Organisasi (X1)

Variable budaya organisasi di ukur dengan menggunakan 21item pernyataan yang dikembangkan oleh Abdullah (2012) dengan lima skala pengukuran yang dimulai dari 1(Sangat tidak setuju), 2(Tidak setuju), 3(Netral), 4(Setuju), dan 5(Sangat setuju).

2. Gaya Kepemimpinan $\left(\mathrm{X}_{2}\right)$

Variabel gaya kepemimpinan diukur dengan menggunakan instrumen yang dikembangkan oleh Gibson (1996). Instrumen terdiri dari 5 item 
gaya kepemimpinan konsiderasi dan 4 item gaya kepemimpinan struktur inisiatif.

3. Sistem Reward (X3)

Variabel system reward yang digunakan dalam penelitian ini adalah instrumen yang menggunakan replikasi dari penelitian Mardiyah \& Listianingsih (2005) dan Suprantiningrum \& Zulaikha (2003). Indikator yang digunakan adalah gaji yang diperoleh, insentif, jenjang karir, serta penghargaan terhadap prestasi kerja dengan lima skala pengukuran yang dimulai dari 1 (Sangat tidak setuju), 2 (Tidak setuju), 3 (Netral), 4(Setuju), dan 5(Sangat setuju).

4. Komitmen organisasi (Z)

Variabel komitmen organisasi diukur dengan menggunakan 6 item pernyataan yang dikembangkan oleh Mowday and Steers (1979) dengan lima skala pengukuran yang dimulai dari 1(Sangat tidak setuju), 2(Tidak setuju), 3(Netral), 4(Setuju), dan 5(Sangat setuju).

5. Kinerja $(Y)$

Variabel kinerja diukur menggunakan 6 item pernyataan yang mengacu pada Bernardin and Russell (1993) dengan lima skala pengukuran yang dimulai dari 1(Sangat tidak setuju), 2(Tidak setuju), 3(Netral), 4(Setuju), dan 5(Sangat setuju).

\section{Teknik Analisis Data Statistik Deskriptif}

Statistik deskriptif merupakan teknik analisis yang digunakan dengan tujuan untuk memberikan gambaranterhadap tanggapan responden mengenai variabel-variabel penelitian yang menunjukan angka kisaran teoritis dan sesungguhnya, rata-rata, serta standar deviasi.

\section{Uji Kualitas Data Uji Validitas}

Uji validitas digunakan untuk menilai sah atau tidaknya suatu kuesioner. Suatu kuesioner dikatakan valid jika pertanyaan kuesioner tersebut mampu mengungkapkan suatu yang diukur oleh kuesioner tersebut. Uji validitas dilakukan dengan menggunakan evaluasi measurement (outer model)yaitu dengan menggunakan convergentvalidity. Convergentvalidity dari measurement model dengan indikator refleksif dapat dilihat dari korelasi antar masing-masing skor indikator dengan skor konstruknya, (Ghozali, 2008). Ukuran refleksif dikatakan tinggi jika berkolerasi lebih dari 0,70 dengan konstruk yang ingin diukur.

\section{Uji Reliabilitas}


Titiek Herwanti \& Animah: Diskriminan dan Konsekuensi Komitmen Organisasi

Uji reliabilitas dilakukan dengan melihat nilai composite reliability yang dilakukan dari hasil perhitungan PLS untuk masing-masing variable maupun konstruk. Suatu variable maupun konstruk dikatakan reliable jika memberikan nilai composite reliability >0,70 (Werts et al. 1974 dalam Ghazali, 2008).

\section{Metode Analisis Data}

Pengukuran antar variabel dalam penelitian ini menggunakan analisis StructuralEquation Modeling (SEM) dengan metode alternatif Partial Least Square (PLS). Persamaan model penelitian ini adalah :

Komit $=\beta_{1} \mathrm{SR}+\beta_{2} \mathrm{GK}+\beta_{3} \mathrm{BMS}+\delta_{1}$

Kin $=\beta_{1}$ Komit $+\beta_{2} S R+\beta_{3} G K+\beta_{4} B M S+\delta_{2}$

Keterangan :

$\mathrm{SR} \quad=$ Sistem Reward

GK = Gaya Kepemimpinan

BMS = Budaya Manajemen Syariah

Komit $=$ Komitmen Organisasi

Kin =Kinerja Karyawan

$\beta=$ Regression Weight

$\delta \quad=$ Disturbance term

\section{HASIL PENELITIAN DAN PEMBAHASAN}

\section{Statistik Deskriptif Masing-Masing Indikator}

Deskripsi data memberikan gambaran dari nilai rata-rata, minimum, maksimum dan standar deviasi dari masing-masing variabel yang digunakan dalam penelitian ini. Analisis deskriptif masing-masing indicator dapat dilihat pada tabel di bawah ini :

Tabel 1 : Statistik Deskriptif

\begin{tabular}{|c|c|c|c|c|c|}
\hline & Jumlah & & & & Standard \\
\hline Indikator & Data & Mean & Min & Max & Deviation \\
\hline BO1 & 144 & 3,840 & 2,000 & 5,000 & 0.752 \\
\hline BO3 & 144 & 4,007 & 2,000 & 5,000 & 0.595 \\
\hline BO5 & 144 & 4,208 & 1,000 & 5,000 & 0.725 \\
\hline BO6 & 144 & 3,819 & 1,000 & 5,000 & 0.910 \\
\hline BO7 & 144 & 4,028 & 2,000 & 5,000 & 0.589 \\
\hline BO8 & 144 & 3,833 & 1,000 & 5,000 & 0.773 \\
\hline BO11 & 144 & 4,007 & 2,000 & 5,000 & 0.583 \\
\hline BO12 & 144 & 4,292 & 3,000 & 5,000 & 0.633 \\
\hline BO15 & 144 & 3,931 & 1,000 & 5,000 & 0.704 \\
\hline
\end{tabular}




\begin{tabular}{|c|c|c|c|c|c|}
\hline \multirow{2}{*}{ Indikator } & \multicolumn{4}{|c|}{ Jumlah } & \multirow{2}{*}{$\begin{array}{l}\text { Standard } \\
\text { Deviation }\end{array}$} \\
\hline & Data & Mean & Min & Max & \\
\hline BO16 & 144 & 3,882 & 1,000 & 5,000 & 0.812 \\
\hline BO18 & 144 & 3,826 & 1,000 & 5,000 & 0.793 \\
\hline BO20 & 144 & 3,757 & 1,000 & 5,000 & 0.844 \\
\hline BO21 & 144 & 4,361 & 2,000 & 5,000 & 0.673 \\
\hline GK1 & 144 & 4,389 & 3,000 & 5,000 & 0.541 \\
\hline GK3 & 144 & 4,431 & 3,000 & 5,000 & 0.548 \\
\hline GK4 & 144 & 4,292 & 3,000 & 5,000 & 0.525 \\
\hline GK5 & 144 & 4,410 & 3,000 & 5,000 & 0.570 \\
\hline GK7 & 144 & 4,347 & 1,000 & 5,000 & 0.627 \\
\hline GK8 & 144 & 4,368 & 2,000 & 5,000 & 0.609 \\
\hline GK9 & 144 & 4,375 & 3,000 & 5,000 & 0.538 \\
\hline SR1 & 144 & 3,958 & 1,000 & 5,000 & 0.686 \\
\hline SR2 & 144 & 4,153 & 2,000 & 5,000 & 0.680 \\
\hline SR3 & 144 & 3,896 & 1,000 & 5,000 & 0.806 \\
\hline SR4 & 144 & 3,993 & 1,000 & 5,000 & 0.821 \\
\hline SR5 & 144 & 3,729 & 1,000 & 5,000 & 0.810 \\
\hline SR7 & 144 & 3,806 & 1,000 & 5,000 & 0.827 \\
\hline SR8 & 144 & 4,000 & 1,000 & 5,000 & 0.782 \\
\hline SR9 & 144 & 3,792 & 1,000 & 5,000 & 0.849 \\
\hline KO1 & 144 & 4,083 & 2,000 & 5,000 & 0.682 \\
\hline KO2 & 144 & 3,917 & 1,000 & 5,000 & 0.731 \\
\hline KO3 & 144 & 3,826 & 1,000 & 5,000 & 0.793 \\
\hline KO4 & 144 & 3,757 & 1,000 & 5,000 & 0.844 \\
\hline KO5 & 144 & 3,819 & 1,000 & 5,000 & 0.910 \\
\hline KO6 & 144 & 4,028 & 2,000 & 5,000 & 0.589 \\
\hline KO8 & 144 & 4,257 & 2,000 & 5,000 & 0.621 \\
\hline KK1 & 144 & 4,181 & 2,000 & 5,000 & 0.652 \\
\hline KK2 & 144 & 4,229 & 2,000 & 5,000 & 0.642 \\
\hline KK3 & 144 & 4,132 & 1,000 & 5,000 & 0.669 \\
\hline KK4 & 144 & 4,306 & 2,000 & 5,000 & 0.604 \\
\hline KK5 & 144 & 4,118 & 1,000 & 5,000 & 0.661 \\
\hline KK6 & 144 & 4,153 & 2,000 & 5,000 & 0.593 \\
\hline
\end{tabular}

Hasil Pengujian Outer Model, Inner Model, dan Goodness of Fit Metode analisis data yang digunakan adalah Struktural Equation Modelling (SEM) berbasis varian atau biasa disebut dengan soft modeling, dengan menggunakan alat analisis Partial Least Square (PLS). Pada penelitian 
ini pengujian dilakukan dengan bantuan program SmartPLS 3.0. Alasan yang menjadi penyebab digunakan PLS dalam suatu penelitian yaitu : 1) PLS merupakan metode analisis data yang didasarkan asumsi data tidak harus berdistribusi normal multivariate (indikator dengan skala kategori, ordinal, interval, sampai ratio dapat digunakan pada model yang sama), sampel tidak harus besar, yaitu jumlah sampel kurang dari 100 atau minimal 30 bisa dilakukan analisis. 2) PLS dapat digunakan untuk mengkonfirmasi teori, yang masih dikatakan lemah, karena PLS dapat digunakan untuk prediksi, tetapi dapat juga digunakan untuk menjelaskan ada atau tidaknya hubungan antar variabel laten. 3) PLS memungkinkan algoritma dengan menggunakan analisis series ordinary least square (OLS) sehingga diperoleh efisiensi perhitungan olgaritma. Keempat, pada pendekatan PLS, diasumsikan bahwa semua ukuran variance dapat digunakan untuk menjelaskan (Ghozali, 20012:4). Tahap pertama dalam smart PLS adalah menilai outer model yaitu proses iterasi indikator dan variabel laten diperlakukan sebagai deviasi (penyimpangan) dari nilai mean (rata-rata) dengan tujuan melihat hubungan antara indikator dengan konstruknya. Pada tahap pertama, Factor loading yang nilainya dibawah 0,50 akan didrop dari analisis (Ghozali dan Latan, 2012). Berdasarkan hasil pengujian (gamber 2) menggunakan smartPLS, dapat diketahui bahwa semua indikator dapat diterima karena sample pada tiap-tiap indikator lebih dari 0,50. 


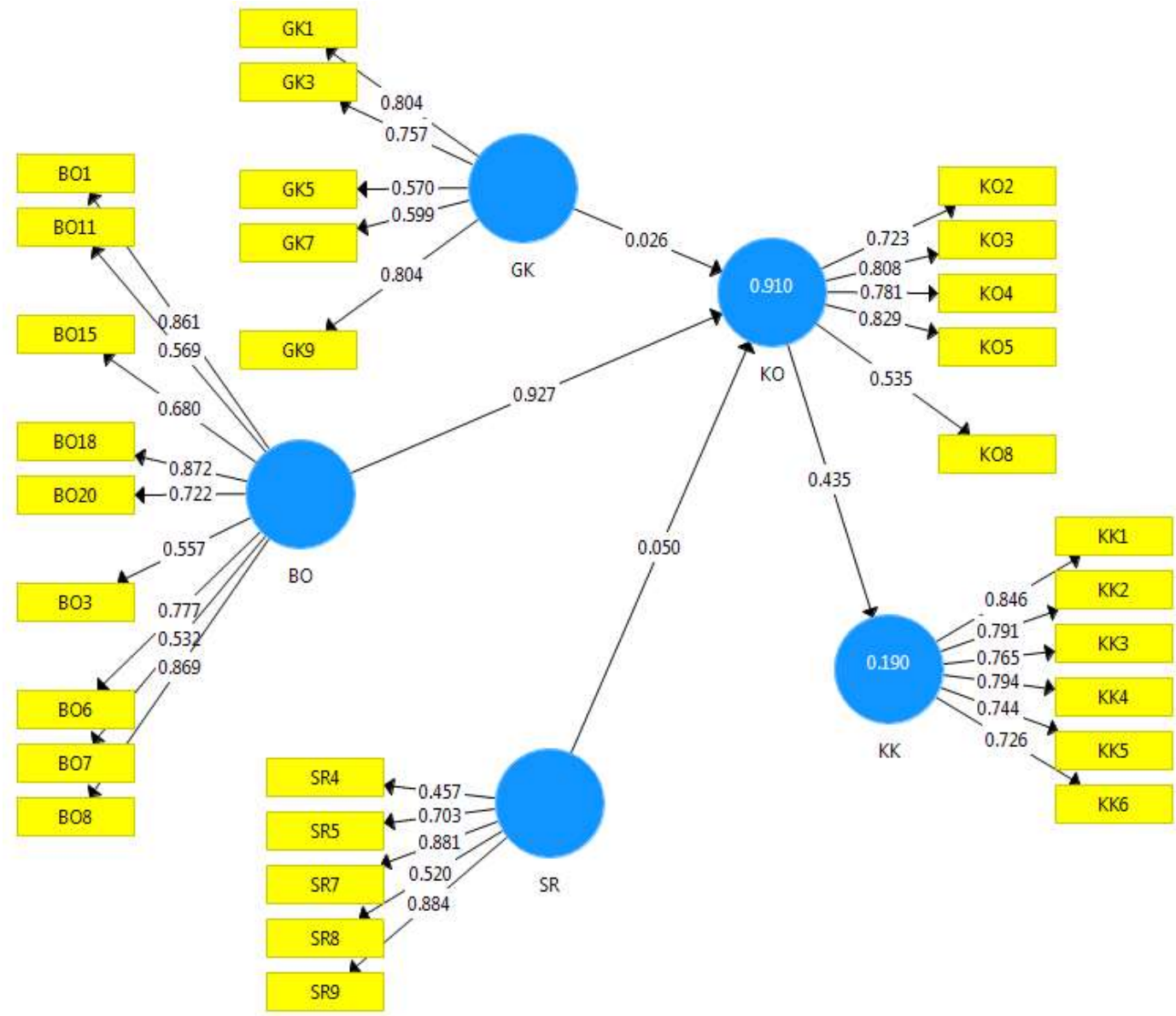

Gambar 2 : Hasil Outer Loading

Tiga kriteria pengukuran digunakan dalam teknik analisa data menggunakan SmartPLS adalah convergent validity, composite reability dan discriminant validity.

1. Convergent validity.

Hasil uji outer loading untuk melihat nilai convergent validity, didapatkan hasil estimasi perhitungan uji outer loading untuk semua indikator pada variabel budaya organisasi (BO), gaya kepemimpinan (GK), system reward (SR), komitmen organisasi (KO), dan kinerja karyawan (KK) adalah valid.

2. Composite Reliability atau Uji Reliabilitas.

Suatu konstruk dikatakan reliabel jika nilai composite reliability maupun cronbach alpha di atas 0,70 (Ghozali, 2008:43). Hal tersebut menunjukan konsistensi dan stabilitas instrumen yang digunakan tinggi.

3. Discriminant Validity diukur dengan membandingkan nilai square root of average variance extracted (AVE) setiap konstruk dengan korelasi antara konstruk dengan konstruk lainya dalam model. Jika nilai akar kuadrat AVE setiap konstruk lebih besar daripada nilai korelasi antar konstruk dengan 
Titiek Herwanti \& Animah: Diskriminan dan Konsekuensi Komitmen Organisasi

konstruk lainnya dalam model maka memiliki nilai discriminant validity yang baik. Hasil discriminant validity Akar AVE konstruk Budaya Organisasi (BO) sebesar 0,727, lebih tinggi daripada korelasi antara Budaya Organisasi (BO) dengan konstruk lainnya dalam model. AVE konstruk variabel selanjutnya yaitu Gaya Kepemimpinan (GK) sebesar 0,714, lebih tinggi dari pada korelasi antara konstruk Gaya Kepemimpinan (GK) dengan konstruk lainnya dalam model. Akar AVE konstruk Kinerja Karyawan (KK) sebesar 0,778, lebih tinggi daripada korelasi antara kinerja karyawan (KK) dengan konstruk lainnya dalam model. Akar AVE konstruk Komitmen Organisasi (KO) sebesar 0,743, lebih tinggi daripada korelasi antara Komitmen Organisasi (KO) dengan konstruk lainnya dalam model. Akar AVE konstruk Sistem Reward (SR) sebesar 0,711, lebih tinggi daripada korelasi antara Sistem Organisasi (SR) dengan konstruk lainnya dalam model.Sehingga dapat dinyatakan memiliki nilai discriminant validity yang baik (Ghozali, 2012:25).

Tabel 2 : Cronbach's Alpha dan Composite Reliability

\begin{tabular}{lllll} 
& & & $\begin{array}{l}\text { Average } \\
\text { Variance }\end{array}$ & keterangan \\
& $\begin{array}{l}\text { Cronbach's } \\
\text { Alpha }\end{array}$ & $\begin{array}{l}\text { Composite } \\
\text { Reliability }\end{array}$ & $\begin{array}{l}\text { Extracted } \\
\text { (AVE) }\end{array}$ & \\
\hline BO & 0.888 & 0.907 & 0.529 & Baik (fit) \\
GK & 0.763 & 0.836 & 0.510 & Baik (fit) \\
KK & 0.874 & 0.902 & 0.606 & Baik (fit) \\
KO & 0.788 & 0.858 & 0.552 & Baik (fit) \\
SR & 0.764 & 0.828 & 0.506 & Baik (fit) \\
\hline
\end{tabular}

\section{Uji Model Struktural (Inner Model)}

Pengujianinner model atau model struktural dilakukan untuk melihat hubungan antar konstruk, nilai signifikansi dan $R$-square dari model penelitian. Model struktural dievaluasi dengan menggunakan $R$-square untuk konstruk dependen. Nilai $R$-square Komitmen Organisasi (KO) sebesar 0,910. Nilai $R$-square sebesar 0,91 memiliki arti bahwa variabel konstruk Komitmen Organisasi (KO)yang dapat dijelaskan oleh variable konstruk Budaya Organisasi (BO), Gaya Kepemimpinan (GK) dan Sistem Reward (SR) sebesar 91 persen sedangkan 9 persen dijelaskan oleh variabel lain di luar yang diteliti. Nilai $R$-square kinerja karyawan (KK) sebesar 0,190. Nilai $R$-square sebesar 0,19 memiliki arti bahwa variabel konstruk Kinerja Karyawan (KK)yang dapat dijelaskan oleh variable konstruk Budaya Organisasi (BO), Gaya Kepemimpinan (GK), Sistem Reward (SR) dan komitmen Organisasi 
(KO) sebesar 19 persen sedangkan 81 persen dijelaskan oleh variabel lain di luar yang diteliti. Semakin besar angka $R$-square menunjukkan semakin besar variabel eksogen tersebut dapat menjelaskan variable endogen sehingga semakin baik persamaan strukturalnya.

\section{Hasil Pengujian Hipotesis dan Pembahasan}

Pengujian hipotesis yang diajukan dilakukan dengan pengujian model struktural (inner model) dengan melihat nilai $R$-square yang merupakan ujigoodness-fitmodel. Selain itu juga dengan melihat path coefficients yang menunjukkan koefisien parameter dan nilai signifikansi statistik. Signifikansi parameter yang diestimasi dapat memberikan informasi mengenai hubungan antar variabel-variabel penelitian. Batas untuk menolak dan menerima hipotesis yang diajukan diatas adalah 1,96 untuk $p<0.05$. Tabel di bawah ini menyajikan output estimasi untuk pengujian model struktural.

Tabel 3 : Path Coefficients (Mean, STDEV, T-Values)

\begin{tabular}{|c|c|c|c|c|c|}
\hline & $\begin{array}{l}\text { Original } \\
\text { Sample } \\
\text { (0) }\end{array}$ & $\begin{array}{l}\text { Sample } \\
\text { Mean } \\
\text { (M) }\end{array}$ & $\begin{array}{l}\text { Standard } \\
\text { Deviation } \\
\text { (STDEV) }\end{array}$ & $\begin{array}{l}\text { T Statistics } \\
(\mid \text { O/STDEV } \mid)\end{array}$ & $\begin{array}{l}\mathrm{P} \\
\text { Values }\end{array}$ \\
\hline $\begin{array}{l}\mathrm{BO}-> \\
\mathrm{KO}\end{array}$ & 0.927 & 0.924 & 0.017 & 56,062 & 0.000 \\
\hline $\begin{array}{l}\text { GK -> } \\
\text { KO } \\
\text { KO -> }\end{array}$ & 0.026 & 0.029 & 0.028 & 0.908 & 0.364 \\
\hline $\begin{array}{l}\text { KK } \\
\text { SR -> }\end{array}$ & 0.435 & 0.451 & 0.088 & 4,920 & 0.000 \\
\hline KO & 0.050 & 0.051 & 0.028 & 1,801 & 0.072 \\
\hline
\end{tabular}

Sumber: Output PLS, (2016)

Berdasarkan hasil output PLS pada Tabel hipotesis 1 yang menyatakan bahwa budaya organisasi berpengaruh signifikan terhadap komitmen organisasi, untuk nilai koefisien jalur menghasilkan nilai sebesar 0,927 . Hasil uji hipotesis menunjukkan path coeficient antara partisipasi penganggaran dengan kinerja aparat memiliki nilai T-statistics $(56,062)>T$-table $(1,96)$ dengan signifikansi level 5\% (two tailed), menunjukkan bahwa budaya organisasi berpengaruh signifikan terhadap komitmen organisasi. Artinya hipotesis 1a diterima. Hal ini menunjukkan bahwa budaya organisasi memberikan pengaruh terhadap komitmen organisasi. Dengan adanya budaya organisasi, maka akansemakin meningkatkan komitmen organisasi tersebut.

Hipotesis 1b yang menyatakan bahwa gaya kepemimpinan berpengaruh signifikan terhadap komitmen organisasi, untuk nilai koefisien 
jalur menghasilkan nilai sebesar 0,026. Hasil uji hipotesis menunjukkan path coeficient antara gaya kepemimpinan dengan komitmen organisasi memiliki nilai $T$-statistics $(0,908)>T$-table $(1,96)$ dengan signifikansi level $5 \%$ (two tailed), menunjukkan bahwa gaya kepemimpinan berpengaruh tidak signifikan terhadap komitmen organisasi. Artinya hipotesis 1b ditolak. Hal ini menunjukkan bahwa gaya kepemimpinan tidak memberikan pengaruh terhadap komitmen organisasi. Dengan adanya gaya kepemimpinan maka tidak meningkatkan komitmen organisasi.

Hipotesis 1c yang menyatakan bahwa sistem reward berpengaruh signifikan terhadap komitmen organisasi, untuk nilai koefisien jalur menghasilkan nilai sebesar 0,050. Hasil uji hipotesis menunjukkan path coeficient antara sistem reward dengan komitmen organisasi memiliki nilai $T$ statistics $(1,801)>$ T-table $(1,96)$ dengan signifikansi level $5 \%$ (two tailed), menunjukkan bahwa sistem reward berpengaruh signifikan terhadap komitmen organisasi. Artinya hipotesis 1c ditolak.Hal ini menunjukkan bahwa sistem reward tidak memberikan pengaruh terhadap komitmen organisasi. Dengan adanya sistem reward yang jelas tidak akan meningkatkan komitmen organisasi.

Hipotesis 2 yang menyatakan bahwa komitmen organisasi berpengaruh signifikan terhadap kinerja karyawan, untuk nilai koefisien jalur menghasilkan nilai sebesar 0,435 . Hasil uji hipotesis menunjukkan path coeficient antara komitmen organisasi dengan kinerja karyawan memiliki nilai T-statistics $(4,92)>T$-table $(1,96)$ dengan signifikansi level $5 \%$ (two tailed), menunjukkan bahwa komitmen organisasi berpengaruh signifikan terhadap kinerja karyawan. Artinya hipotesis 2 diterima.Hal ini menunjukkan bahwa komitmen organisasi memberikan pengaruh terhadap kinerja karyawan. Dengan adanya komitmen organisasi yang jelas maka akansemakin meningkatkan kinerja karyawan.

Hasil pengujian Hipotesis 1bmenunjukkan budaya organisasi berpengaruh signifikan terhadap komitmen organisasi(sebagai variabel intervening) dan komitmen organisasi berpengaruh signifikan terhadap kinerja kinerja karyawan. Pengujian hipotesis mediasi dilakukan dengan prosedur yang dikembangkan oleh Sobel (1982) yang dikenal dengan uji Sobel (Sobel test). Besarnya pengaruh tidak langsung ini dapat dihitung dengan mengalikan koefisien $(a \times b)=(0,927 \times 0,435)=0,403$.

Besarnya Standard error tidak langsung variabel budaya organisasi terhadap kinerja karyawan merupakan perkalian dari pengaruh variabel budaya organisasi terhadap komitmen organisasi, dengan variabel komitmen organisasi terhadap kinerja karyawan. Hasil perhitungan diperoleh sebagai berikut : 


$$
\begin{aligned}
\text { Sab } & =\sqrt{\mathrm{b}^{2} \mathrm{Sa}^{2}+\mathrm{a}^{2} \mathrm{Sb}^{2}+\mathrm{Sa}^{2} \mathrm{Sb}^{2}} \\
& =\sqrt{(0,435)^{2}(0,017)^{2}+(0,927)^{2}(0,088)^{2}+(0,017)^{2}(0,088)^{2}} \\
& =\sqrt{0,000055+0,0067+0,000002} \\
& =\sqrt{0,006757}=\mathbf{0 , 0 8 2 2}
\end{aligned}
$$

Sehingga nilai $\mathrm{t}$ diperoleh, $\mathrm{t}=\frac{\mathrm{ab}}{\mathrm{Sab}}=\frac{0,403}{0,0822}=4,9027$

Nilai T-statistics $(4,9027)>T$-table $(1,96)$ dengan signifikansi level $5 \%$ (two tailed), menunjukkan bahwa budaya organisasi berpengaruh signifikan terhadap kinerja karyawan dengan komitmen organisasisebagai variabel intervening. Artinya hipotesis 3a diterima. Hal ini menunjukkan bahwa komitmen organisasi sebagai variabel intervening dan memberikan pengaruh dalam hubungan antara budaya organisasi terhadap kinerja karyawan.

Hasil pengujian Hipotesis 3bmenunjukkan gaya kepemimpinan berpengaruh signifikan terhadap komitmen organisasi(sebagai variabel intervening) dan komitmen organisasi berpengaruh signifikan terhadap kinerja kinerja karyawan. Pengujian hipotesis mediasi dilakukan dengan uji Sobel (Sobel test). Besarnya pengaruh tidak langsung ini dapat dihitung dengan mengalikan koefisien $(a \times b)=(0,026 \times 0,435)=0,01131$

Besarnya Standard error tidak langsung variabel gaya kepemimpinan terhadap kinerja karyawan merupakan perkalian dari pengaruh variabel gaya kepemimpinan terhadap komitmen organisasi, dengan variabel komitmen organisasi terhadap kinerja karyawan. Hasil perhitungan diperoleh sebagai berikut :

$$
\begin{aligned}
\text { Sab } & =\sqrt{\mathrm{b}^{2} \mathrm{Sa}^{2}+\mathrm{a}^{2} \mathrm{Sb}^{2}+\mathrm{Sa}^{2} \mathrm{Sb}^{2}} \\
& =\sqrt{(0,435)^{2}(0,028)^{2}+(0,026)^{2}(0,088)^{2}+(0,028)^{2}(0,088)^{2}} \\
& =\sqrt{0,000148+0,0000052+0,000128} \\
& =\sqrt{0,0002812}=\mathbf{0 , 0 1 6 8}
\end{aligned}
$$

Sehingga nilai $\mathrm{t}$ diperoleh, $\mathrm{t}=\frac{\mathrm{ab}}{\mathrm{Sab}}=\frac{0,01131}{0,0168}=0,67321$

Nilai $T$-statistics $(0,67321)<T$-table $(1,96)$ dengan signifikansi level $5 \%$ (two tailed), menunjukkan bahwa gaya kepemimpinan berpengaruh tidak signifikan terhadap kinerja karyawan dengan komitmen organisasibukan sebagai variabel intervening. Artinya hipotesis 3b ditolak. Hal ini menunjukkan bahwa komitmen organisasi tidak sebagai variabel intervening dan tidak memberikan pengaruh dalam hubungan antara gaya kepemimpinan terhadap kinerja karyawan.

Hasil pengujian Hipotesis $\mathbf{3 b}$ menunjukkan sistem reward berpengaruh signifikan terhadap komitmen organisasi(sebagai variabel intervening) dan komitmen organisasi berpengaruh signifikan terhadap kinerja kinerja karyawan. Pengujian hipotesis mediasi dilakukan dengan uji Sobel (Sobel 
Titiek Herwanti \& Animah: Diskriminan dan Konsekuensi Komitmen Organisasi

test). Besarnya pengaruh tidak langsung ini dapat dihitung dengan mengalikan koefisien $(a \times b)=(0,050 \times 0,435)=0,02175$

Besarnya Standard error tidak langsung variabel sistem reward terhadap kinerja karyawan merupakan perkalian dari pengaruh variabel sistem reward terhadap komitmen organisasi, dengan variabel komitmen organisasi terhadap kinerja karyawan. Hasil perhitungan diperoleh sebagai berikut :

$$
\begin{aligned}
\text { Sab } & =\sqrt{\mathrm{b}^{2} \mathrm{Sa}^{2}+\mathrm{a}^{2} \mathrm{Sb}^{2}+\mathrm{Sa}^{2} \mathrm{Sb}^{2}} \\
& =\sqrt{(0,435)^{2}(0,028)^{2}+(0,050)^{2}(0,088)^{2}+(0,028)^{2}(0,088)^{2}} \\
& =\sqrt{0,189 \cdot 0,0008+0,0025 \cdot 0,0077+0,0008 \cdot 0,0077} \\
& =\sqrt{0,00015+0,000019+0,000006} \\
& =\sqrt{0,000175}=\mathbf{0 , 0 1 3 2}
\end{aligned}
$$

Sehingga nilai t diperoleh, $\mathrm{t}=\frac{\mathrm{ab}}{\mathrm{Sab}}=\frac{0,02175}{0,0132}=1,65$

Nilai T-statistics $(1,65)>T$-table $(1,96)$ dengan signifikansi level $5 \%$ (two tailed), menunjukkan bahwa sistem reward tidak berpengaruh signifikan terhadap kinerja karyawan dan komitmen organisasibukan sebagai variabel intervening. Artinya hipotesis 3c ditolak. Hal ini menunjukkan bahwa komitmen organisasi sebagai variabel intervening dan memberikan pengaruh dalam hubungan antara sistem reward terhadap kinerja karyawan.

\section{Pembahasan Hasil Pengujian Hipotesis}

\section{Pengaruh Budaya Organisasi Terhadap Komitmen Organisasi}

Fishbein dan Ajzen (dalam Yuliana, 2004) memaparkan, planned behavior theory didasarkan atas pendekatan terhadap beliefs yang dapat mendorong individu untuk melakukan perilaku tertentu. Sedangkan menurut Ikhsan dan Ishak (2005) menyatakan bahwa budaya merupakan suatu titik pandang yang pada saat bersamaan dijadikan jalan hidup oleh suatu masyarakat. Jadi budaya (beliefs) ini dapat membuat seseorang untuk memiliki komitmen terhadap organisasi (Puspasari, 2000).

Hipotesis pertama menyatakan bahwa budaya organisasi berpengaruh terhadap komitmen organisasi. Hasil pengujian hipotesis melalui PLS menunjukkan bahwa nilai T-statistik < t-tabel, yaitu 30,3096 > 1,96. Hal ini menunjukkan bahwa budaya organisasi berpengaruh terhadap komitmen organisasi. Semakin kuat budaya organisasi (budaya manajemen syariah) diimplementasikan dalam kegiatan pelayanan, maka semakin karyawan memiliki komitmen yang tinggi terhadap perusahaan. Hal ini sejalan dengan penelitian terdahulu dari Puspasari (2000) yang menyimpulkan bahwa budaya organisasi berpengaruh terhadap komitmen organisasi.

Temuan ini juga mendukung teori planned behavior, bahwa munculnya sikap yang memengaruhi perilaku adalah melalui suatu proses pengambilan 
keputusan yang teliti dan beralasan, dan dampaknya terbatas hanya pada tiga hal, yaitu: (a) perilaku tidak banyak ditentukan oleh sikap umum, tetapi oleh sikap spesifik terhadap suatu perilaku; (b) perilaku tidak hanya dipengaruhi oleh sikap, tetapi juga dipengaruhi oleh norma subyektif; (c) sikap terhadap perilaku bersama dengan norma subyektif membentuk intensi untuk melakukan suatu perilaku tertentu (Fishbein \& Ajzen, 1975). Budaya manajemen syariah dipegang kuat oleh masyarakat muslim yang beriman di dalam implementasi dalam kehidupan sehari-hari tidak hanya di rumah, di tempat bekerja maupun di dalam lingkungan dimana mereka berada. Budaya manajemen syariah mengutamakan : ahlak, pembelajaran, pelayanan, silaturahim-kemitraan serta internalisasi agama dalam kehidupan seorang pemimpin karena setiap manusia adalah pemimpin. Oleh karena nilai-nilai yang dianut di dalam budaya manajemen syariah sehingga membuat karyawan memiliki yang tinggi terhadap pekerjaannya.

\section{Pengaruh Gaya Kepemimpinan Terhadap Komitmen Organisasi}

Path goal theory menjelaskan dampak perilaku pimpinan pada motivasi bawahan, kepuasan dan kinerjanya. Ada empat gaya kepemimpinan menurut Robert House, yaitu direktif, suportif, partisipatif dan berorientasi pada prestasi (Luthans, 2005). Sedangkan Kreitner \& Kinicki (2005) menyatakan bahwa gaya kepemimpinan manajer akan berpengaruh terhadap efektivitas kelompok kerja.

Hipotesis kedua menyatakan bahwa gaya kepemimpinan berpengaruh terhadap komitmen organisasi . Hasil pengujian hipotesis melalui PLS menunjukkan bahwa nilai T-statistik < t-tabel, yaitu 2,029 >1,96. Hal ini menunjukkan bahwa gaya kepemimpinan berpengaruh terhadap komitmen organisasi. Semakin bagus gaya kepemimpinan, maka semakin karyawan memiliki komitmen yang tinggi terhadap perusahaan. Hal ini sejalan dengan penelitian terdahulu dari Yiing \& Ahmad (2009) yang menyimpulkan bahwa gaya kepemimpinan berpengaruh terhadap komitmen organisasi.

\section{Pengaruh Sistem Reward Terhadap Komitmen Organisasi}

Teori Kebutuhan Maslow mengidentifikasi lima tingkat dalam hirarki kebutuhan yaitu kebutuhan fisiologis (gaji, sandang, pangan, papan), kebutuhan keamanan (rencana senioritas, asuransi kesehatan, uang pesangon, pensiun), kebutuhan cinta, kebutuhan pekerjaan dan aktualisasi diri (Luthans, 2005).

Hipotesis ketiga menyatakan bahwa system reward berpengaruh terhadap komitmen organisasi . Hasil pengujian hipotesis melalui PLS menunjukkan bahwa nilai T-statistik < t-tabel, yaitu 1,9817 > 1,96. Hal ini 
Titiek Herwanti \& Animah: Diskriminan dan Konsekuensi Komitmen Organisasi

menunjukkan bahwa sistem reward berpengaruh terhadap komitmen organisasi. Semakin bagus system reward, maka semakin karyawan memiliki komitmen yang tinggi terhadap perusahaan. Hal ini sejalan dengan penelitian terdahulu dari Ruvendi (2005) yang menyimpulkan bahwa system reward berpengaruh terhadap komitmen organisasi.

\section{Pengaruh Komitmen Organisasi Terhadap Kinerja Karyawan}

Teori penguatan memiliki kontinjensi penguatan yaitu berkaitan dengan urutan-urutan antara stimulus, tanggapan, dan konsekuensi dari perilaku yang ditimbulkan. Suatu kondisi kerja tertentu dibentuk oleh organisasi (stimulus), kemudian karyawan bertindak sebagaimana diinginkan oleh organisasi (tanggapan). Dari sudut pandang motivasi, penggunaan stimulus atau konsekuensi akan memotivasi karyawan untuk melakukan perilaku yang diinginkan oleh organisasi. Semakin pendek interval waktu antara tanggapan atau respon karyanan dengan pemberian imbalan maka semakin besar pengaruhnya terhadap perilaku (Ikhsan \& Ishak, 2005).

Hipotesis keempat menyatakan bahwa komitmen organisasi berpengaruh terhadap kinerja karyawan. Hasil pengujian hipotesis melalui PLS menunjukkan bahwa nilai T-statistik < t-tabel, yaitu 8,083 >1,96. Hal ini menunjukkan bahwa komitmen organisasi berpengaruh terhadap kinerja karyawan. Semakin bagus komitmen karyawan, maka semakin bagus kinerjanya. Hal ini sejalan dengan penelitian terdahulu dari Syauta et.al (2012) yang menyimpulkan bahwa organisasi berpengaruh terhadap kinerja karyawan.

\section{Pengaruh Budaya Organisasi Terhadap Kinerja Karyawan Melalui Komitmen Organisasi}

Sesuai dengan planned behavior theory didasarkan atas pendekatan terhadap beliefs yang dapat mendorong individu untuk melakukan perilaku tertentu (Adjen dalam Yuliana, 2004). Oleh karena itu, maka individu akan berusaha untuk melakukan tindakan / berperilaku yang di dasarkan pada nilai-nilai yang dianut, yang dalam hal ini seorang muslim yang beriman akan memiliki nilai-nilai yang di dasarkan pada syariah. Selain itu di dalam teori penguatan dinyatakan bahwa perilaku merupakan fungsi dari aktibat yang berkaitan dengan perilaku tersebut (Ikhsan \& Ishak, 2005)

Hipotesis kelima menyatakan bahwa budaya organisasi berpengaruh terhadap kinerja karyawan melalui komitmen organisasi. Hasil pengujian hipotesis melalui PLS menunjukkan bahwa nilai T-statistik < t-tabel, yaitu 4,9027> 1,96. Hal ini menunjukkan bahwa budaya organisasi berpengaruh terhadap kinerja karyawan melalui komitmen organisasi. Semakin budaya 
manajamen syariah diimplementasikan dengan baik, maka karyawan akan semakin memiliki komitmen yang tinggi, hal ini membawa dampak terhadap peningkatan kinerja karyawan. Hal ini sejalan dengan penelitian terdahulu dari puspasari (2000), Maramis (2013) yang menyimpulkan bahwa budaya organisasi berpengaruh terhadap komitmen organisasi dan kinerja karyawan.

\section{Pengaruh Gaya Kepemimpinan Terhadap Kinerja Karyawan Melalui Komitmen Organisasi}

Sesuai dengan path goal theoryperilaku pimpinan pada motivasi bawahan, kepuasan dan kinerjanya. Ada empat gaya kepemimpinan menurut Robert House, yaitu direktif, suportif, partisipatif dan berorientasi pada prestasi (Luthans, 2005). Oleh karena itu karyawan berperilaku sesuai dengan arahan dan gaya kepemimpinan dari pimpinan perusahaan. Selain itu perilaku merupakan fungsi dari aktibat yang berkaitan dengan perilaku tersebut. Teori penguatan memiliki kontinjensi penguatan yaitu berkaitan dengan urutan-urutan antara stimulus, tanggapan, dan konsekuensi dari perilaku yang ditimbulkan. Suatu kondisi kerja tertentu dibentuk oleh organisasi (stimulus), kemudian karyawan bertindak sebagaimana diinginkan oleh organisasi (tanggapan). Dari sudut pandang motivasi, penggunaan stimulus atau konsekuensi akan memotivasi karyawan untuk melakukan perilaku yang diinginkan oleh organisasi. Semakin pendek interval waktu antara tanggapan atau respon karyanan dengan pemberian imbalan maka semakin besar pengaruhnya terhadap perilaku (Ikhsan \& Ishak, 2005)

Hipotesis keenam menyatakan bahwa gaya kepemimpinan berpengaruh terhadap kinerja karyawan melalui komitmen organisasi. Hasil pengujian hipotesis melalui PLS menunjukkan bahwa nilai T-statistik > ttabel, yaitu 0,67321>1,96. Hal ini menunjukkan bahwa gaya kepemimpinan tidak berpengaruh terhadap kinerja karyawan melalui komitmen organisasi. Hal ini tidak sejalan dengan penelitian terdahulu dari Yiing \& Ahmad (2009) yang menyimpulkan bahwa gaya kepemimpinan berpengaruh berpengaruh terhadap kinerja karyawan melalui komitmen organisasi.

\section{Pengaruh Sistem Reward Terhadap Kinerja Karyawan Melalui Komitmen Organisasi}

Sesuai dengan teori kebutuhan maslow yang terdiri dari 5 kebutuhan yaitu: kebutuhan kebutuhan fisiologis (gaji, sandang, pangan, papan), kebutuhan keamanan (rencana senioritas, asuransi kesehatan, uang pesangon, pensiun), kebutuhan cinta, kebutuhan pekerjaan dan aktualisasi diri (Luthans, 2005), maka seseorang akan memiliki komitmen yang tinggi terhadap pekerjaan jika diberikan kecukupan atas kebutuhan hidupnya. 
Selain itu di dalam teori penguatan dinyatakan bahwa perilaku merupakan fungsi dari aktibat yang berkaitan dengan perilaku tersebut (Ikhsan \& Ishak,2005) sehingga jika karyawan memiliki komitmen yang tinggi terhadap pekerjaan, maka kinerjanya akan semakin baik.

Hipotesis ketujuh menyatakan bahwa system reward berpengaruh terhadap kinerja karyawan melalui komitmen organisasi. Hasil pengujian hipotesis melalui PLS menunjukkan bahwa nilai T-statistik > t-tabel, yaitu $1,65>1,96$. Hal ini menunjukkan bahwa sistem reward tidak berpengaruh terhadap kinerja karyawan melalui komitmen organisasi. Hal ini tidak sejalan dengan penelitian terdahulu dari Ruvendi (2005) yang menyimpulkan bahwa system reward berpengaruh terhadap kinerja karyawan melalui komitmen organisasi.

\section{SIMPULAN DAN SARAN}

Penelitian ini bertujuan untuk menguji dan menganalisis pengaruh penerapa budaya organisasi, gaya kepemimpinan, system reward terhadap kinerja karyawan melalui komitmen organisai pada KSPPS se pulau Lombok Planned behavior theory, teory penguatan, path goal theory dan teory kebutuhan maslow digunakan untuk menjelaskan fenomena terkait determinan dan konsekuensi komitmen organisasi. Dengan metode purposive sampling, penelitian ini menggunakan data dari 49 KSPPS se pulau Lombok. Proses pengolahan data menggunakan alat analisis Partial Least Square (smartPLS) 3.0.

Hasil penelitian menunjukan bahwa terdapat pengaruh langsung yang siginifikan antara budaya organisasi, gaya kepemimpinan, system reward terhadap komitmen organisasi. Temuan lain mengungkapkan bahwa budaya organisasi, gaya kepemimpinan, system reward, komitmen organisasi berpengaruh langsung terhadap kinerja karyawan. Penelitian ini menemukan bukti bahwa variabel komitmen organisasi merupakan variabel intervening yang dapat mempengaruhi hubungan antara budaya organisasi terhadap kinerja karyawan. Selanjutnya penelitian ini tidak menemukan bukti bahwa bahwa variabel komitmen organisasi merupakan variabel intervening yang dapat mempengaruhi hubungan antara gaya kepemimpinan dan system reward terhadap kinerja karyawan.

Oleh karena itu bagi manajemen, hendaknya menerapkan budaya manajemen syariah di dalam pengelolaan KSPPS karena mampu membuat karyawan untuk komitmen terhadap organisasi sehingga berdampak terhadap kinerja karyawan 
Bagi peneliti selanjutkan dapat mencoba untuk menjadikan variable budaya manajemen syariah untuk organisasi konvensional atau meneliti pada perbankan syariah.

\section{DAFTAR PUSTAKA}

Abdullah,M.Ma'ruf, 2012. Manajemen Berbasis Syariah. Aswaja Presindo. Yogyakarta

Ajzen, I. (2005). Attitudes, personality, and behavior ( $2^{\text {nd }}$ ed.). Berkshire: Open University Press..

Arifin, Noor. 2010.Analisis Budaya Organisasional Terhadap Komitmen Kerja Karyawan Dalam Peningkatan Kinerja Organisasional Karyawan Pada Koperasi Bmt Di Kecamatan Jepara. Jurnal Ekonomi \& Pendidikan, Volume 8 Nomor 2, November

Collison, C and Parcell, G 2001, Learning to Fly, Capstone, UK.

Ghozali, Imam,. Hengky Latan. 2012. Partial Least Square, Konsep, Teknik dan Aplikasi SMARTPLS 2.0 M3 Untuk Penelitian Bisnis. Badan Penerbit UNDIP. Semarang.

Gibson James. L, Ivancevich John M dan Donnely James H, Jr. 1996. Organisasi: Perilaku, Struktur dan Proses. Terjemahan. Jilid 1. Penerbit Binarupa Aksara, Jakarta.

Fleishman, A dan Peters, D.R. 1962. Leadership Attitudes and Managerial "Success", Personel Psychology. 127-143.

Ikhsan,Arfan.Ishak,Muhammad.2005.Akuntansi Keperilakuan.Salemba Empat. Jakarta

Ivancevich, Konopaske Dan Matteson. 2006. Perilaku Manajemen Dan Organisasi. alih bahasa Gina Gania. Jakarta : Erlangga.

Kurniawan,Dedi. Lubis.A Rahman, Adam Muhammad.Pengaruh Budaya Kerja Dan Motivasi Kerja Terhadap Kinerja Karyawan International Federation Red Cross (Ifrc) Banda Aceh. Jurnal Manajemen Pascasarjana Universitas Syah Kuala.Volume 1, No. 1, Agustus .

Kreitner dan Kinichi. 2005. Organization Behavior. Irwin. McGraw-Hill, Boston. Luthans, Fred, 2006, "Perilaku Organisasi", Edisi Sepuluh, Penerbit Andi, Yogyakarta

Mardiyah, Aida Ainul \& Listianingsih. 2005. "Pengaruh Sistem Pengukuran Kinerja, Sistem Reward, dan Profit Center Terhadap Hubungan Antara Total Quality Management dengan Kinerja Manajerial". Seminar Nasional Akuntansi VIII. Hal 565-583.

Mas'ud,Fuad.2004.Survai Diagnosis Organisasional Konsep \& Aplikasi.Badan Penerbit Universitas Diponegoro.Semarang 
Titiek Herwanti \& Animah: Diskriminan dan Konsekuensi Komitmen Organisasi

Mowday, R.,\&Steers,RM.(1979).TheMeasurement

Organizational

Commitment.Journal Of Vacational Behavior,Vol 14.pp.224-247

Mulyadi,2007.Sistem Perencanaan dan Pegendalian Manajemen.Salemba

Empat. Jakarta

Nurjanah, 2008. Pengaruh Gaya Kepemimpinan Dan Budaya Organisasi

Terhadap Komitmen Organisasi Dalam Meningkatkan Kinerja

Karyawan.Tesis Magister Manajemen Universitas Diponegoro

Robbins,P.Stephen,1996.Perilaku Organisasi.Jilid 2 Edisi Bahasa Indonesia.PT

Buana Ilmu Populer.Jakarta

Ruvendi Ramlan.2005.Imbalan dan Gaya Kepemimpinan Pengaruhnya terhadap Kepuasan Kerja Karyawan di Balai Besar Industri Hasil Pertanian Bogor. Jurnal.

Setyorini, Christina Tri. Maghfiroh, Siti.Farida, Yusriati Nur.2012.Pengaruh Budaya Organisasi, Komitmen Organisasi dan Keterlibatan Kerja Terhadap Kinerja Karyawan Baitul Maal Wat Tamwil (BMT). Media Riset Akuntansi.

Suprantiningrum \& Zulaikha. 2003. "Pengaruh Total Quality Management Terhadap Kinerja Manajerial dengan Sistem Pengukuran Kinerja dan Sistem Penghargaan (Reward) Sebagai Variabel Moderating". Seminar Nasional Akuntansi VI. Hal. 775-790.

Susilo.2013.Pengaruh Disiplin Kerja Dan Budaya Organisasi Terhadap Kinerja Guru Smp Negeri Di Kecamatan Bandar Kabupaten Batang. Tesis Program Studi Manajemen Pendidikan IKIP PGRI Semarang

Wibowo, 2013.Manajemen Kinerja. Raja Grafindo Persada Jakarta

Wirawan,2013.Kepemimpinan : Teori, Psikologi, Perilaku Organisasi, Aplikasi dan Penelitian. Raja Grafindo Persada Jakarta

Yousef, A. Davish. 2000. Organizational Commitment: A Mediator of The Relationships of Leadership Behavior With Job Satisfaction and Performance in A Non-Western Country. Journal of Management Psychology, (15) : 6-28 